\title{
FEATURES OF TOLL-LIKE RECEPTOR TYPE 9 EXPRESSION ON IMMUNOCOMPETENT PERIPHERAL BLOOD CELLS OF PATIENTS WITH MEASLES INFECTION OF VARYING SEVERITY
}

\author{
Kseniia Veklych', Nikolay Popov², Tetiana Liadova ${ }^{3}$, Alexander Martynenko ${ }^{4}$, Olga Volobueva $^{5}$, \\ Olesia Hololobova ${ }^{6}$, Olga Sorokina ${ }^{7}$ Olena Salyenkova ${ }^{8}$, Vladislava Sarkis-Ivanova ${ }^{9}$
}

${ }^{1}$ Department of General and Clinical Immunology and Allergology, School of Medicine, V. N. Karazin Kharkiv National University, Kharkiv, Ukraine

k.veklich@karazin.ua

ORCID: https://orcid.org/0000-0001-9826-3316

${ }^{2}$ Department of General and Clinical Immunology and Allergology, School of Medicine, V. N. Karazin Kharkiv National University, Kharkiv, Ukraine

ORCID: https://orcid.org/0000-0002-5759-9654

${ }^{3}$ Department of General and Clinical Immunology and Allergology, School of Medicine, V. N. Karazin Kharkiv National University, Kharkiv, Ukraine

ORCID: https://orcid.org/0000-0002-5892-2599

${ }^{4}$ School of Medicine, V. N. Karazin Kharkiv National University, Kharkiv, Ukraine

ORCID: https://orcid.org/0000-0002-0609-2220

${ }^{5}$ Department of General and Clinical Immunology and Allergology, School of Medicine, V. N. Karazin Kharkiv National University, Kharkiv, Ukraine

ORCID: https://orcid.org/0000-0002-5569-1748

${ }^{6}$ Department of General and Clinical Immunology and Allergology, School of Medicine, V. N. Karazin Kharkiv National University, Kharkiv, Ukraine

ORCID: https://orcid.org/0000-0002-1111-2302

${ }^{7}$ Department of General and Clinical Immunology and Allergology, School of Medicine, V. N. Karazin Kharkiv National University, Kharkiv, Ukraine

ORCID: http://orcid.org/0000-0001-6646-544X

${ }^{8}$ Department of General and Clinical Immunology and Allergology, School of Medicine, V. N. Karazin Kharkiv National University, Kharkiv, Ukraine

ORCID: https://orcid.org/0000-0001-5170-5447

${ }^{9}$ Department of Hygiene and Ecology No. 1, Kharkiv National Medical University, Kharkiv, Ukraine ORCID: https://orcid.org/0000-0002-3953-550X

ARTICLE INFO

Article history:

Received date 16.03 .2021

Accepted date 2704.2021

Published date 30.04 .2021

Section:

Practical medicine

DOI

$10.21303 / 2313-8416.2021 .001810$

KEYWORDS

measles

Toll-like receptor

cytokines

immunoglobulins

interferon

\section{ABS TRACT}

Object of research: the level of the Toll-like receptor type 9 expression on peripheral blood lymphocytes and monocytes in patients with measles of varying severity, both with and without complications.

The solved problem: identification of the relationship between changes in the level of production of the main cytokines and virus-specific immunoglobulins and the level of expression of the Tolllike receptor type 9 on immunocompetent peripheral blood cells of patients with measles infection of varying severity.

The main scientific results: In patients with measles infection have been identified three types of cytokine response, each of which is characterized by different levels of changes in the expression of the main cytokines, immunoglobulins, and their avidity. It was shown that the levels of expression of major cytokines and virus-specific antibodies, as well as their avidity, are associated with the level of expression of the Toll-like receptor type 9. It has been demonstrated that moderate disease is associated with a significant increase in the level of expression of the Toll-like receptor type 9 on the immunocompetent peripheral blood cells, while their low expression leads to the development of severe forms of the disease. It has been shown that in moderate disease the risk of complications is associated with a lower level of expression of the Toll-like receptor compared to the group without complications. In groups of patients with a severe course of the disease a significant decrease in the level of expression of the Toll-like receptor type 9 was shown to be associated with the risk of complications.

The field of practical use of the research results: medical institutions specializing in the treatment of socially significant infectious diseases.

Innovative technological product: a method of advanced study of patients with and without measles infection of varying severity which allows to identify risk groups for the development of severe forms of the disease and complications, which in turn will allow the timely apply methods of immunomodulatory therapy and optimize the costs of the health system.

Scope of application of an innovative technological product: inpatient and outpatient treatment and diagnostics of patients with socially significant infectious diseases.

(C) The Author(s) 2021. This is an open access article under the Creative Commons CC BY license 


\section{Introduction}

\section{1. The object of research}

The object of research is the level of the Toll-like receptor type 9 expression on peripheral blood lymphocytes and monocytes in patients with measles of varying severity, both with and without complications.

\section{2. Problem description}

Measles is a highly contagious viral infectious disease characterized by the development of general intoxication, fever, catarrhal syndrome, conjunctivitis and the development of a typical exanthema. The persistence of the measles virus in the human body also leads to immunosuppression which in turn is a prerequisite for a high susceptibility of the affected organism to the addition of various secondary pathogens [1-3].

One of the main complications of measles infection is the affection of the respiratory tract, namely out-of-hospital pneumonia which is the cause of high mortality among patients with measles $[4,5]$. During the last measles outbreak, which was observed on the territory of Ukraine in 2017-2019, high mortality rates were due not only to the action of the virus itself, but also to the addition of secondary bacterial flora and the development of out-of-hospital pneumonia, which against the background of immunosuppression caused by the direct action of the virus had a severe course even with the use of powerful antibacterial agents.

An important link in a macroorganism protection from pathogen penetration is the innate immune response which uses pattern recognition receptors (PRRs) to detect microorganisms invased the human body. PRRs recognize endogenous and exogenous ligands, including pathogen-associated molecular patterns (PAMPs), which are chemical motifs expressed by microorganisms. The most fully characterized type of pattern recognition receptors which are important modulators of the innate immune response due to the ability to recognize microorganisms localized both in the intercellular space and inside cells, are Toll-like receptors (TLRs). TLRs are the class of pattern PRRs that detect microorganisms that have entered the human body by recognizing PAMPs. Once PAMPs are detected TLRs trigger a signal transmission cascade that leads to the production of inflammatory mediators. Toll-like receptors represent important modulators of the innate immune response since they are able to recognize microorganisms localized both in the intercellular space and inside cells. The fact that TLRs are widely represented in the body's cells confirms their central role in potential pathogens recognition. Ligands for TLR are double-stranded RNA (dsRNA), single-stranded RNA (ssRNA), viral and bacterial RNA or unmethylated CPG DNA motifs resulting from hydrolytic degradation of microorganisms [6, 7].

One of the most important TLRs is the Toll-like receptor type 9. Activation of this receptor expression and signal transmission with its involvement are important mechanisms for triggering an innate immune response which leads to the activation of various structures depending on the cell type. In cDC, pDC and macrophages TLR9 activate the signal transmission cascade culminating in the production of proinflammatory cytokines - TNF $\alpha$, IL-6 and IL-12, and interferon (IFN) type $1[8,9]$. TLR9 has also been shown to be important in protecting the body from lung tissue affection caused by S.Pneumoniae and S.aureus [10-13].

Previous studies on the involvement of TLR9 in signal transmission have shown that receptor activation occurs after their interaction with unmethylated CpG DNA. However, in-depth studies conducted in recent years demonstrate the critical importance of these receptors in the case of damage to the body by RNA-containing viruses.

Jiang $\mathrm{J}$ et al.in their study involving to HIV-1- exposed seronegative individuals, demonstrated that levels of TLR9 expression and interferon-7 regulation factor were higher in the group of seronegative individuals exposed to HIV-1, indicating that increased expression of TLR9 pathway molecules in monocytes may be involved in mediating these individuals ' resistance to HIV1. The authors also studied the levels of antiviral factors and chemokines associated with both the TLR9 pathway and HIV-1 infection/replication, and demonstrated that seronegative individuals exposed to HIV-1, compared with the control group of patients, show an increase in IFN $\alpha$, MIP$1 \mathrm{~A}$ and MIP-1B in peripheral blood mononuclears at the level of mRNA and IFN $\beta$, MIP-1A, MIP-1B and RANTES at the level of protein in plasma. Thus, the authors demonstrated that increased activity of the TLR9 pathway in monocytes/macrophages contributes to a decrease in 
the susceptibility of monocytic dendritic cells to HIV-1 in seronegative individuals exposed to HIV-1 [14].

In addition, Yanyan Liao et all in the study of drug users demonstrated that a decrease in TLR9 expression and activity resulting from drug use is accompanied by a decrease in key factors and cytokines of the TLR9 pathway and contributes to HIV infection and its replication in macrophages [15].

\section{3. Suggested solution to the problem}

Despite understanding the importance of TLR9 in activation of the innate immune response to pathogen penetration, the role of this receptor in protecting the body from socially significant diseases is poorly understood. That is why given the significant number of patients with measles infection who were treated in Kharkiv Regional Clinical Infectious Diseases Hospital (Ukraine), immunological disorders that were detected in these patients $[16,17]$, as well as a significant number of patients with bacterial complications from the respiratory tract, it was considered interesting to study the level of Toll-like receptor expression in this cohort of patients and establish a relationship between the level of its expression, the degree of immunological disorders and the presence of complications.

Aim of the research: to determine the dependence of the severity of measles infection and the risk of complications on changes in the activity of the Toll-like receptors type 9 expression on immunocompetent peripheral blood cells.

\section{Materials and methods}

The study included 65 patients diagnosed with measles who were treated in the Kharkiv Regional Clinical Infectious Diseases Hospital (Ukraine) between 2017 and 2019. The inclusion criteria were the presence of measles of varying severity, both with and without complications. Patients were divided into 4 groups depending on the severity of the disease and the presence of complications. Group 1 included patients who had moderate diseases without complications and were treated in the general department $(n=20)$; group 2 included patients with moderate measles who had complications in the form of out-of-hospital pneumonia and were treated in the general department $(n=20)$; group 3 included patients with severe measles who had no complications and were treated in the intensive care unit $(n=16)$; group 4 included patients with severe measles who had complications in the form of out-of-hospital pneumonia and were treated in the intensive care unit $(n=9)$. The average age of patients was $36.16 \pm 1.59$ years, women $-48 \%$, men $-52 \%$. Patients were admitted to the hospital on $5.18 \pm 0.15$ day from the onset of the disease and $4.29 \pm 0.12$ day from the appearance of the rash. The diagnosis was established on the basis of the presence of typical clinical signs of the disease (catarrhal and intoxication syndromes, eye damage syndrome, enanthema and exanthema syndrome with a typical stage of appearance and disappearance of rashes), data from objective, instrumental and laboratory research methods, epidemiological data (contact with patients with an established diagnosis of measles). The presence of pneumonia was confirmed by chest X-ray. All patients reported receiving measles vaccination in childhood. The control group consisted of 20 voluntary donors who at the time of blood sampling did not have clinical signs of measles, did not have contact with measles patients and did not have exclusion criteria (the presence of concomitant acute and chronic diseases from various organs and systems, immunosuppressive and autoimmune diseases, taking immunosuppressive drugs, performing surgical interventions 6 months before hospitalization because of measles, giving birth 6 months before hospitalization because of measles).

All voluntary donors reported having been vaccinated against measles in childhood and never had measles during their lifetime. During the study, the provisions of the Helsinki Declaration of the World Medical Association, the ethical code of the doctor of Ukraine and informing the patient about the nature of the study were strictly observed. All patients involved in the study signed informed consent to participate in the study. Protocol No. 2 of the Commission on Biomedical Ethics of V. N. Karazin Kharkiv National University of the Ministry of Science of Ukraine dated 10.04.2021.

On the day of admission to the hospital the level of expression of Toll-like receptor type 9 in the leukocyte suspension was determined in all patients. The study was performed using Flow Cytometry using a set of TLR9 monoclonal antibodies (CD123+) (Germany) in accordance with the manufacturer's instructions. Also, with the help of solid-phase enzyme-linked immunosorbent assay 
method the concentration in the blood serum of pro-and anti-inflammatory cytokines (IL-1, IL-6, IL-4, IL-10), IFN $\alpha$ and IFN $\gamma$ as well as the level of virus-specific IgM, IgA and IgG with the level of avidity of the latter were determined using test systems manufactured by JSC "Vector-best" (Russian Federation), "Hema" (Ukraine), "The Native Antigen Company" (USA) according to the manufacturer's instructions. A correlation analysis between the expression of Toll-like recetors and serum concentrations of pro- and anti- inflammatory cytokines as well as IFN $\alpha$ and IFN $\gamma$ was also performed.

Statistical processing of the obtained data was performed using the IBM SPSS Statistics 22.0 program. The data in the tables are presented as the arithmetic mean $(M) \pm$ average error of the arithmetic mean $(\mathrm{m})$. When interpreting the significance of the difference in results, the Mann-Whitney criterion was used, and $p<0.05$ was considered the critical value of the significance level. When performing correlation-regression analysis, the Pearson correlation coefficient (critical value of the Student's coefficient $p<0.05$ ) was used.

\section{Research results}

The study of the levels of pro- and anti-inflammatory cytokines and INF $\alpha$ and INF $\gamma$ in the blood serum on the day of admission to the hospital showed an increase in them in all groups of patients compared with the control group. In patients of group 1 the level of IL-1 (CI: 45.1-154.6) and IL-6 (CI: 100.02-185.9) in the serum increased 3.9 times, INF $\alpha-2.8$ times (CI: 95.21-122.75), INF $\gamma$ - 2.5 times (CI: 93.2-111.2), IL-4 and IL-10 - 3.7 times (CI: 80.91-104.89) and 3.6 times (CI: 56.3-80.88). In patients of group 2 these indiced increased by 3.2 (CI: 61.6-101.8); 3.2 (CI: 84.6159.5); 2.4 (CI: 88.01-97.0); 1.7 (CI: 65.92-80.01); 3.0 (CI: 60.1-88.8); and 2.8 times (CI: 44.0862.12), respectively. In patients of group 3, the level of IL-1 increased 2.6 times (CI: 52.2-84.0), IL-6 - 1.9 times (CI: 55.1-86.3), INF $\alpha-1.7$ times (CI: 64.6-77.3), INF $\gamma-1.3$ times (CI: 47.9-57.9), IL-4 - 1.4 times (CI: 26.9-46.7), IL- $10-1.1$ times (CI: 16.6-25.9). In patients of group $4-$ levels of IL-1, IL-6, IL-4 and IL-10 increased by 1.03 (CI: 21.3-31.44), 1.01 (CI: 17.4-56.6), 1.04 (CI: 14.9-36.3) and 1.06 times (CI: 13.22-25.1), respectively; levels of INF $\alpha$ and INF $\gamma$ in patients of this group were lower than in the control group - 1.06 (CI: 27.1-44.3) and 1.1 times (CI: 28.8-45.9), respectively (Fig. 1).

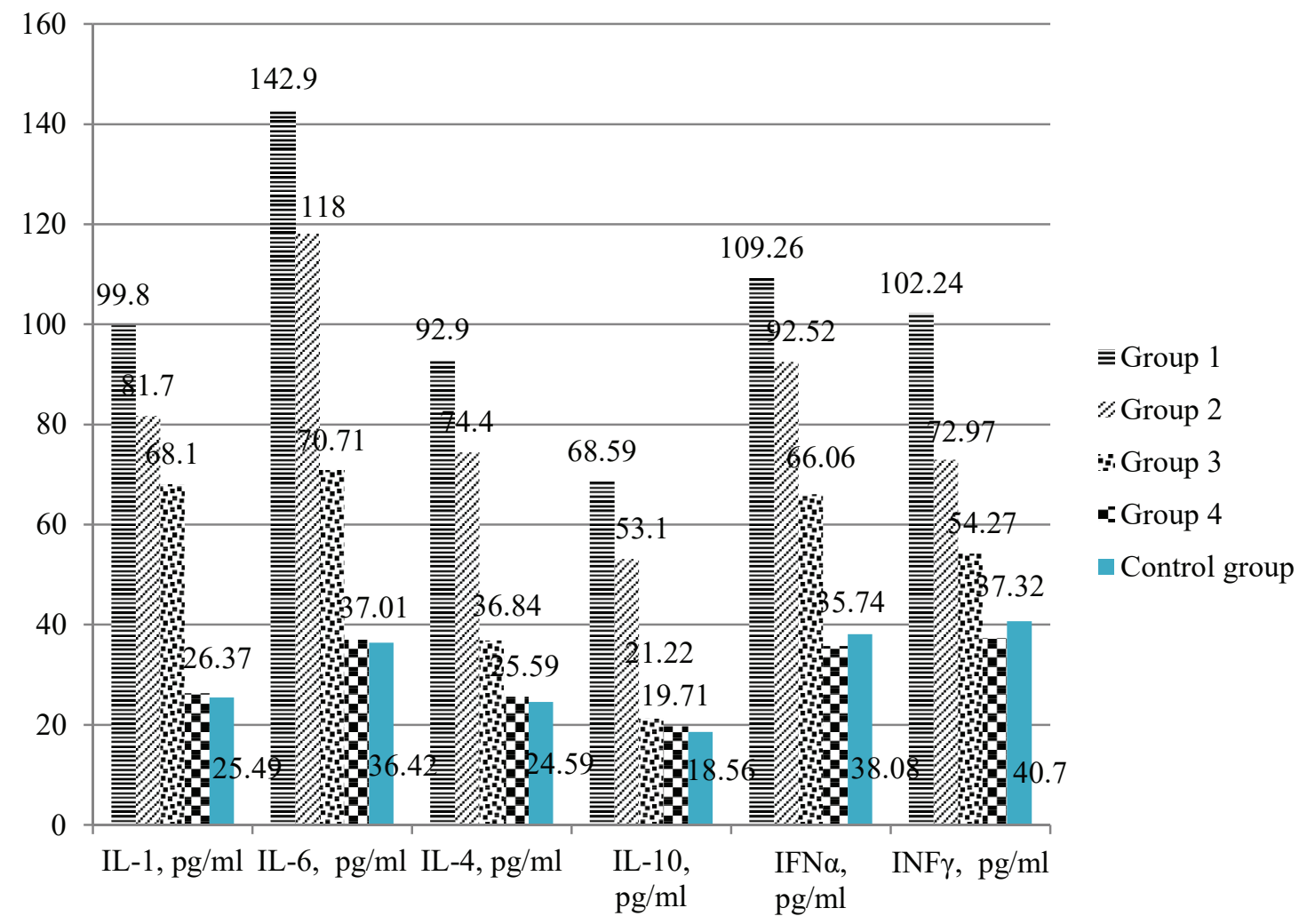

Fig. 1. Cytokine profile in patients of groups 1-4 at the day of admission 
The study of the levels of specific IgG and IgA as well as IgG avidity on the day of admission to the hospital showed a decrease in their levels in relation to the control group in all groups of patients, while the lowest rates were recorded in patients of group 4 who had a severe course of the disease and the development of pneumonia. In comparison with the indices of individuals of the control group. In patients of group 1 the level of $\operatorname{IgA}$ in patients was reduced by 1.13 times (CI: $0.04-0.26), \operatorname{IgG}$ was reduced by 1.2 times (CI: $0.96-1.47)$, IgG avidity was reduced by 1.09 times (CI: 83.98-88.7); in patients of group 2 the indices were reduced by 1.7 (CI: $0.06-0.13), 1.28$ (CI: 0.94-1.33) and 1.17 times (CI: 76.83-83.0), respectively. In patients of group 3 the level of IgA was reduced by 2.42 times (CI: $0.03-0.12)$, IgG was reduced by 1.75 times (0.61-1.07), IgG avidity was reduced by 1.37 times (CI: 65.26-71.81); in patients of group 4 the indices were reduced by 3.4 (CI:0.02-0.07), 1.98 (CI: 0.59-1.12) and 1.76 times (CI: 50.15-58.94), respectively. Also in patients of all groups the presence of Ig class $\mathrm{M}$ which were absent in individuals of the control group was observed (Fig. 2, 3).

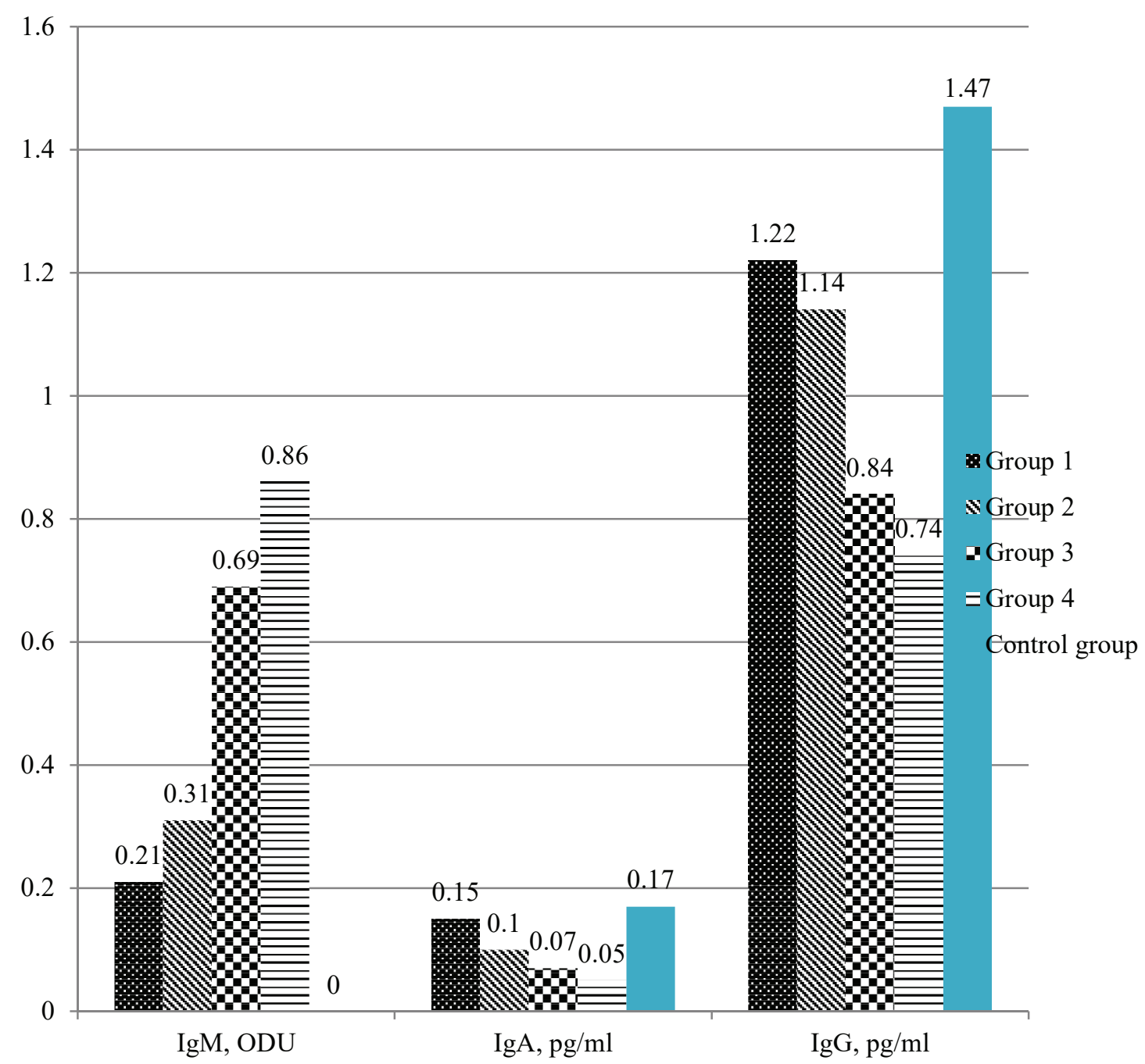

Fig. 2. Levels of $\operatorname{IgA}, \operatorname{IgG}, \operatorname{IgM}$ in patients of groups $1-4$ at the day of admission

Analysis of data obtained by studying the level of Toll-like receptor type 9 expression showed that in patients of groups 1 and 2 who had a normoreactive type of cytokine response and significantly higher levels of IgA and IgG, the level of TLR9 expression on peripheral blood mononuclears was higher than in people of the control group; in patients of group 1 the level of TLR9 expression was by 2.53 times (CI:1.44-2.82), and in patients of group 2 by 1.96 times (CI: 1.11-2.18) higher than in people of the control group. In patients of group 3 who had a dissociative type of cytokine response and a more significant, comparing to patients of groups 1 and 2, decrease 
in IgA and IgG levels, the level of TLR9 expression was by 1.33 times (CI: 0.59-0.87) lower than in the control group. In patients of group 4 who had a hyporeactive type of cytokine response and a statistically significant decrease in IgA and IgG levels, the level of TLR9 expression was the lowest; in patients of this group the TLR9 expression index was by 1.35 times (CI: $0.53-0.70)$ lower than in the control group (Table 1).

Avidity, \%

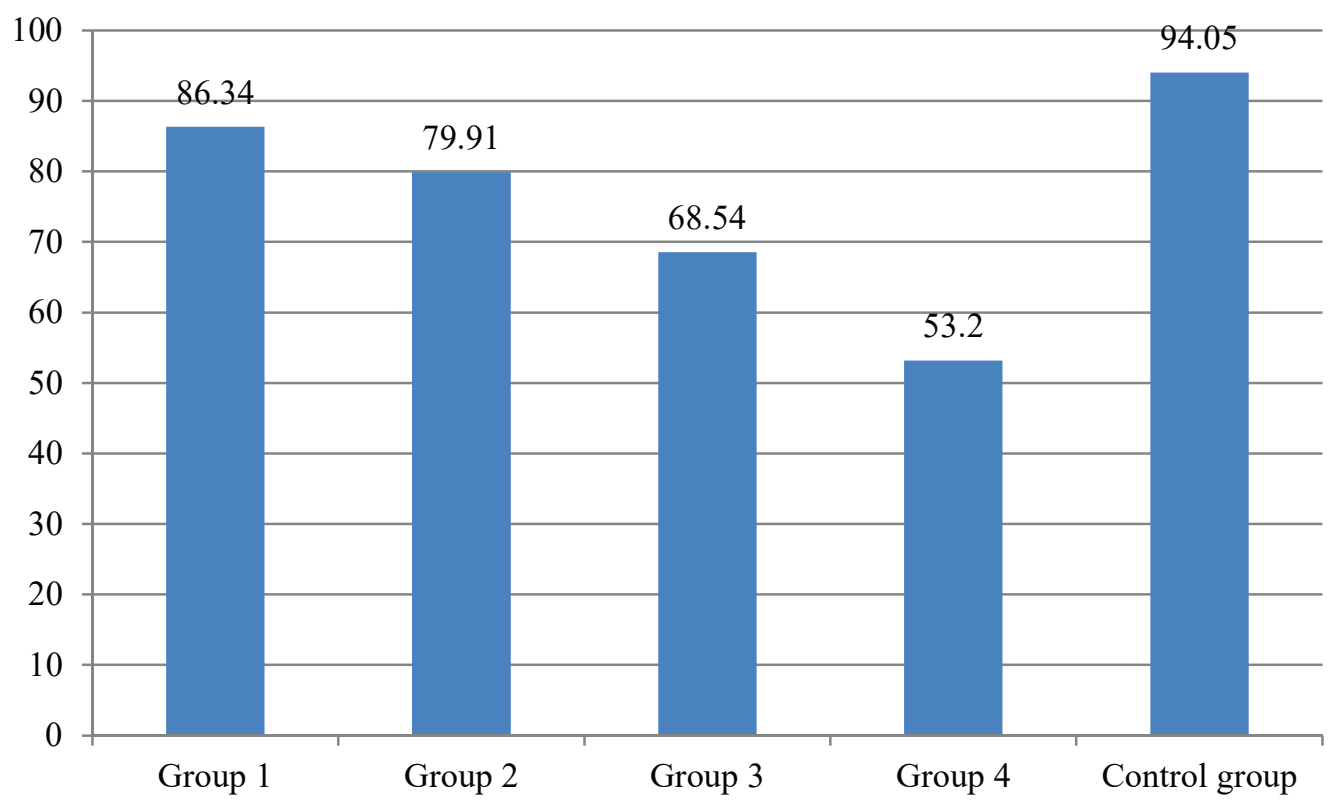

Fig. 3. The IgG avidity in patients of groups $1-4$ at the day of admission

Table 1

TLR9 expression levels, cytokine profile indices and specific immune response of patients of groups 1-4 at the day of admission

\begin{tabular}{|c|c|c|c|c|c|c|c|c|c|c|c|}
\hline Indices & $\begin{array}{c}\text { TLR9 }^{+} \\
\text {CD289 }^{+} \\
\% \\
\end{array}$ & $\begin{array}{l}\text { IFN } \alpha \\
\text { pg/ml }\end{array}$ & $\begin{array}{l}\text { IFN } \gamma \\
\mathrm{pg} / \mathrm{ml}\end{array}$ & $\begin{array}{c}\text { IL-1, pg/ } \\
\text { ml }\end{array}$ & $\begin{array}{c}\text { IL-6, pg/ } \\
\mathrm{ml}\end{array}$ & $\begin{array}{c}\mathrm{IL}-4, \mathrm{pg} / \\
\mathrm{ml}\end{array}$ & $\begin{array}{l}\text { IL-10, } \\
\mathrm{pg} / \mathrm{ml}\end{array}$ & $\begin{array}{l}\text { IgM, } \\
\text { ODU }\end{array}$ & $\begin{array}{c}\text { IgA, pg/ } \\
\text { ml }\end{array}$ & $\begin{array}{l}\text { IgG, } \\
\mathrm{pg} / \mathrm{ml}\end{array}$ & $\begin{array}{c}\text { Avidity, } \\
\%\end{array}$ \\
\hline Group $1(n=20)$ & $\begin{array}{l}2.13 \pm \\
\pm 0.34^{*}\end{array}$ & $\begin{array}{c}109.26 \pm \\
\pm 6.74^{*}\end{array}$ & $\begin{array}{c}102.24 \pm \\
\pm 4.41^{*}\end{array}$ & $\begin{array}{l}99.8 \pm \\
\pm 26.83^{*}\end{array}$ & $\begin{array}{l}142.9 \pm \\
\pm 21.05^{*}\end{array}$ & $\begin{array}{l}92.9 \pm \\
\pm 5.88^{*}\end{array}$ & $\begin{array}{l}68.59 \pm \\
\pm 6.02^{*}\end{array}$ & $\begin{array}{c}0.21 \pm \\
\pm 0.06^{*}\end{array}$ & $\begin{array}{l}0.15 \pm \\
\pm 0.06\end{array}$ & $\begin{array}{l}1.22 \pm \\
\pm 0.13\end{array}$ & $\begin{array}{l}86.34 \pm \\
\pm 1.16^{*}\end{array}$ \\
\hline Group $2(n=20)$ & $\begin{array}{l}1.65 \pm \\
\pm 0.26^{*}\end{array}$ & $\begin{array}{l}92.52 \pm \\
\pm 2.21^{*}\end{array}$ & $\begin{array}{l}72.97 \pm \\
\pm 3.45^{*}\end{array}$ & $\begin{array}{l}81.7 \pm \\
\pm 9.87^{*}\end{array}$ & $\begin{array}{l}118.0 \pm \\
\pm 17.84^{*}\end{array}$ & $\begin{array}{l}74.4 \pm \\
\pm 7.04^{*}\end{array}$ & $\begin{array}{l}53.1 \pm \\
\pm 4.42^{*}\end{array}$ & $\begin{array}{c}0.31 \pm \\
\pm 0.06^{*}\end{array}$ & $\begin{array}{c}0.1 \pm \\
\pm 0.02\end{array}$ & $\begin{array}{c}1.14 \pm \\
\pm 0.1\end{array}$ & $\begin{array}{l}79.91 \pm \\
\pm 1.51^{*}\end{array}$ \\
\hline Group $3(n=16)$ & $\begin{array}{l}0.73 \pm \\
\pm 0.07\end{array}$ & $\begin{array}{l}66.06 \pm \\
\pm 3.54^{*}\end{array}$ & $\begin{array}{l}54.27 \pm \\
\pm 2.66^{*}\end{array}$ & $\begin{array}{l}68.10 \pm \\
\pm 7.71^{*}\end{array}$ & $\begin{array}{l}70.71 \pm \\
\pm 7.54^{*}\end{array}$ & $\begin{array}{l}36.84 \pm \\
\pm 4.79^{*}\end{array}$ & $\begin{array}{l}21.22 \pm \\
\pm 2.24\end{array}$ & $\begin{array}{l}0.69 \pm \\
\pm 0.09^{*}\end{array}$ & $\begin{array}{l}0.07 \pm \\
\pm 0.02\end{array}$ & $\begin{array}{l}0.84 \pm \\
\pm 0.11^{*}\end{array}$ & $\begin{array}{l}68.54 \pm \\
\pm 1.59^{*}\end{array}$ \\
\hline Group $4(n=9)$ & $\begin{array}{l}0.62 \pm \\
\pm 0.04\end{array}$ & $\begin{array}{c}35.74 \pm \\
\pm 3.95\end{array}$ & $\begin{array}{c}37.32 \pm \\
\pm 3.94\end{array}$ & $\begin{array}{l}26.37 \pm \\
\pm 2.33\end{array}$ & $\begin{array}{l}37.01 \pm \\
\pm 9.00\end{array}$ & $\begin{array}{c}25.59 \pm \\
\pm 4.92\end{array}$ & $\begin{array}{l}19.71 \pm \\
\pm 2.73\end{array}$ & $\begin{array}{l}0.86 \pm \\
\pm 0.13^{*}\end{array}$ & $\begin{array}{l}0.05 \pm \\
\pm 0.01^{*}\end{array}$ & $\begin{array}{c}0.74 \pm \\
\pm 0.10^{*}\end{array}$ & $\begin{array}{l}53.2 \pm \\
\pm 2.02^{*}\end{array}$ \\
\hline $\begin{array}{l}\text { Control group } \\
\qquad(n=20)\end{array}$ & $\begin{array}{l}0.84 \pm \\
\pm 0.02\end{array}$ & $\begin{array}{c}38.08 \pm \\
\pm 2.34\end{array}$ & $\begin{array}{l}40.7 \pm \\
\pm 2.29\end{array}$ & $\begin{array}{c}25.49 \pm \\
\pm 1.88\end{array}$ & $\begin{array}{l}36.42 \pm \\
\pm 2.02\end{array}$ & $\begin{array}{l}24.59 \pm \\
\pm 2.02\end{array}$ & $\begin{array}{c}18.56 \pm \\
\pm 1.66\end{array}$ & 0 & $\begin{array}{l}0.17 \pm \\
\pm 0.05\end{array}$ & $\begin{array}{l}1.47 \pm \\
\pm 0.13\end{array}$ & $\begin{array}{l}94.05 \pm \\
\pm 0.47\end{array}$ \\
\hline
\end{tabular}

Note: ${ }^{*}-p<0.05$ between the indices of patients and the control group

\section{Discussion}

The study of the cytokine profile of measles patients revealed three types of cytokine response to the infectious process: normoreactive, dissociative, and hyporeactive. The normoreactive type of cytokine response was observed in patients of groups 1 and 2 , in whom the disease had a moderate course and was characterized by a statistically significant $(p<0.05)$ increase in the levels of pro- and anti-inflammatory cytokines and IFNs compared to individuals of the control group. In patients of group 3, in whom the disease had a severe course and was not accompanied by the development of complications, a dissociative type of cyto- 
kine response was detected, which was characterized by a significant increase in the levels of pro-inflammatory cytokines and low levels of anti-inflammatory cytokines, as well as IFN $\alpha$ and IFN $\gamma$. Patients of group 4 in whom the disease was severe and accompanied by the development of pneumonia, had a hyporeactive type of cytokine response, which was characterized by low levels of pro- and anti-inflammatory cytokines, the concentrations of which were slightly higher than those of the control group, and interferons, the levels of which were lower than those of the control group. As indicated by D. Griffin [3], the interaction of measles birus hemagglutinin $(\mathrm{H})$ with monocytes leads to the activation of IL-6 production, and the interaction of the measles virus with epithelial cells leads to an increase in the production of IL-8. In vivo studies also confirmed an increase in the level of IL-1 and IL-8 protein in the blood plasma of children infected with measles.

With regard to anti-inflammatory cytokines it was demonstrated that the production of Th cells type 1 which is observed at the initial stages of infection, in a later period is replaced by the production of type 2 cytokines - IL-4, IL-10 and IL-13 the increased levels of which are observed and after clinical recovery of patients [18].

The study found that measles in patients of groups 1-4 occurred against a background of low levels of specific antibodies. It is noteworthy that in patients of groups 3 and 4 the level of specific IgM on the day of hospitalization was high and significantly higher $(p<0.05)$ than in patients of groups 1 and 2, that can be considered as indirect evidence of the predominance of the immune system response to infection by primary type and ineffectiveness of conducted routine vaccination. These data confirm the data obtained by Brigitta Laksono et all [1] that demonstrated notional decrease of $\operatorname{IgG}^{+}$and $\operatorname{Ig} \mathrm{A}^{+}$memory $\mathrm{B}$ cells before and after measles. Also in children included in their study blood serum was negative for measles virus-specific IgG prior the infection and afer the infection become measles virus-specific IgG and $\operatorname{IgM}$ positive.

It is noteworthy that among patients with a normoreactive type of cytokine response in patients of group 2, in which the disease had a moderate course but was accompanied by the development of pneumonia, the increase in TLR9 expression was less significant, compared with patients of group 1, who had no complications. Also noteworthy is a significant decrease in the level of TLR9 expression in patients of group 4 who had a severe course of the disease with the development of extrahospital pneumonia. These data are consistent with the results of D.Parker and A. Prince [13] which showed better survival rates in S. aureus-infected mice Tlr9-/-compared to WT mice.

A Pearson correlation analysis performed on the day of admission showed a direct correlation between TLR9 expression levels and serum levels of IFN $\alpha$, IFN $\gamma$, and pro-inflammatory cytokines (IL-1 and IL-6). An inverse correlation was established with respect to anti-inflammatory cytokines - interleukins 4 and 10 .

In relation to IFN $\alpha$, a direct high correlation was found in all study groups; the dependence of the stadied traits in all groups was statistically significant $(p<0.05)$. The correlation between TLR9 expression levels and IFN $\gamma$ levels ranged from weak to noticeable; the dependence of stadied traits in all groups was statistically significant $(p<0.05)$. Determination of the correlation between the level of TLR9 expression and the level of IL-1 established a direct correlation between the indicess, while in patients of groups 1-3 the dependence of signs was statistically significant, and in patients of group 4 - statistically insignificant $(p>0.05)$.

For anti-inflammatory cytokines - interleukin 4 and 10 - a negative correlation was found with the level of TLR9 expression. The statistical significance of the relationship between the studied indices in all groups was absent $(p>0.05)$, and the strength of the relationship ranged from weak to high.

Study limitations. The study included adult patients with measles of verying severity (B05) according to the ICD 10 both with and without complications.

Prospects for further research. The study of an affection of TLR9 expression activity on immunocompetent cells of the peripheral blood can be used to better understand immune system disorders in patients with viral diseases as a predictor and possible factor in the severity of the disease and the development of complications. 


\section{Conclusions}

Measles infection of moderate severity, characterized by a normoreactive type of cytokine response, significant increase in medium- and high-avidity antibodies and a reaction of the immune system by a secondary type, is associated with a significant activation of the TLR9 expression on immunocompetent peripheral blood cells.

A decrease in the level of TLR9 expression leads to the development of a severe course of the disease. At the same time, a 1.15-fold decrease is associated with the development of a hyporeactive type of cytokine response, a decrease in the level of virus-specific IgG and their avidity, but is not accompanied by the development of complications, while a 1.35 -fold decrease in the level of TLR9 expression is associated with the development of a severe complicated course of measles infection, a dissociative type of cytokine response, a significant decrease in the levels of virus-specific Igs, their low avidity and a reaction of the immune system by a primary type.

The level of the Toll-like receptor type 9 expression on immunocompetent peripheral blood cells of patients with measles infection can be considered as an important factor affecting the state of the immune system and the strength of the immunological response in response to the penetration of the pathogen.

The study of the level of the Toll-like receptor type 9 expression will allow to identify groups at risk of severe forms of the disease and complications development, to timely apply methods of an immunomodulatory therapy in such groups of patients and, thereby, to optimize the costs of the health system.

\section{Conflict of interests}

The authors declare that they have no conflicts of interest.

\section{References}

[1] Laksono, B. M., de Vries, R. D., Verburgh, R. J., Visser, E. G., de Jong, A., Fraaij, P. L. A. et. al. (2018). Studies into the mechanism of measles-associated immune suppression during a measles outbreak in the Netherlands. Nature Communications, 9 (1). doi: http://doi.org/10.1038/s41467-018-07515-0

[2] De Vries, R. D., de Swart, R. L. (2014). Measles Immune Suppression: Functional Impairment or Numbers Game? PLoS Pathogens, 10 (12), e1004482. doi: http://doi.org/10.1371/journal.ppat.1004482

[3] Laksono, B., de Vries, R., McQuaid, S., Duprex, W., de Swart, R. (2016). Measles Virus Host Invasion and Pathogenesis. Viruses, 8 (8), 210. doi: http://doi.org/10.3390/v8080210

[4] Schoini, P., Karampitsakos, T., Avdikou, M., Athanasopoulou, A., Tsoukalas, G., Tzouvelekis, A. (2019). Measles pneumonitis. Advances in Respiratory Medicine, 87 (1), 63-67. doi: http://doi.org/10.5603/arm.a2019.0010

[5] Li, J., Zhao, Y., Liu, Z., Zhang, T., Liu, C., Liu, X. (2015). Clinical report of serious complications associated with measles pneumonia in children hospitalized at Shengjing hospital, China. The Journal of Infection in Developing Countries, 9 (10), 1139-1146. doi: http://doi.org/10.3855/jidc.6534

[6] Kawasaki, T., Kawai, T. (2014). Toll-Like Receptor Signaling Pathways. Frontiers in Immunology, 5. doi: http://doi.org/10.3389/ fimmu.2014.00461

[7] El-Zayat, S. R., Sibaii, H., Mannaa, F. A. (2019). Toll-like receptors activation, signaling, and targeting: an overview. Bulletin of the National Research Centre, 43 (1). doi: http://doi.org/10.1186/s42269-019-0227-2

[8] Combes, A., Camosseto, V., N’Guessan, P., Argüello, R. J., Mussard, J., Caux, C. et. al. (2017). BAD-LAMP controls TLR9 trafficking and signalling in human plasmacytoid dendritic cells. Nature Communications, 8 (1). doi: http://doi.org/10.1038/ s41467-017-00695-1

[9] Martínez-Colón, G. J., Warheit-Niemi, H., Gurczynski, S. J., Taylor, Q. M., Wilke, C. A., Podsiad, A. B. et. al. (2019). Influenza-induced immune suppression to methicillin-resistant Staphylococcus aureus is mediated by TLR9. PLOS Pathogens, 15 (1), e1007560. doi: http://doi.org/10.1371/journal.ppat.1007560

[10] Gahlot, S., Nasreen, N., Johnson, J. A., Sahn, S. A., Mohammed, K. A. (2017). Heme Oxygenase-1 Deficiency Diminishes Methicillin-Resistant Staphylococcus aureus Clearance Due to Reduced TLR9 Expression in Pleural Mesothelial Cells. PLOS ONE, 12 (1), e0169245. doi: http://doi.org/10.1371/journal.pone.0169245

[11] Van der Meer, A. J., Achouiti, A., van der Ende, A., Soussan, A. A., Florquin, S., de Vos, A. et. al. (2016). Toll-Like Receptor 9 Enhances Bacterial Clearance and Limits Lung Consolidation in Murine Pneumonia Caused by Methicillin-Resistant Staphylococcus aureus. Molecular Medicine, 22 (1), 292-299. doi: http://doi.org/10.2119/molmed.2015.00242 
[12] Zhang, S., Jia, X., Zhang, Q., Zhang, L., Yang, J., Hu, C. et. al. (2019). Neutrophil extracellular traps activate lung fibroblast to induce polymyositis-related interstitial lung diseases via TLR9-miR-7-Smad2 pathway. Journal of Cellular and Molecular Medicine, 24 (2), 1658-1669. doi: http://doi.org/10.1111/jcmm.14858

[13] Parker, D., Prince, A. (2012). Staphylococcus aureus Induces Type I IFN Signaling in Dendritic Cells Via TLR9. The Journal of Immunology, 189 (8), 4040-4046. doi: http://doi.org/10.4049/jimmunol.1201055

[14] Jiang, J., Hu, X., Li, W., Liu, J., Liang, B., Chen, H. et. al. (2020). Enhanced Signaling Through the TLR9 Pathway Is Associated With Resistance to HIV-1 Infection in Chinese HIV-1-Exposed Seronegative Individuals. Frontiers in Immunology, 11. doi: http://doi.org/10.3389/fimmu.2020.01050

[15] Liao, Y., Jiang, J., Liang, B., Wei, F., Huang, J., Pan, P. et. al. (2017). Opiate use inhibits TLR9 signaling pathway in vivo: possible role in pathogenesis of HIV-1 infection. Scientific Reports, 7 (1). doi: http://doi.org/10.1038/s41598-017-12066-3

[16] Veklych, K. A., Popov, M. M., Liadova, T. I., Sorokina, O. G. (2020). The nature of a specific immune response to measles infection of varying severity. Bulletin of Problems Biology and Medicine, 4 (1), 100-104. doi: http://doi.org/10.29254/ 2077-4214-2020-4-158-100-104

[17] Veklych, K. A., Popov, N. N., Liadova, T. I., Sorokina, O. G. (2020). Autoimmune markers in measles infection of varying severity. Actual Problems of the Modern Medicine: Bulletin of Ukrainian Medical Stomatological Academy, 20 (4), 11-16. doi: http://doi.org/10.31718/2077-1096.20.4.11

[18] Marongiu, L., Gornati, L., Artuso, I., Zanoni, I., Granucci, F. (2019). Below the surface: The inner lives of TLR4 and TLR9. Journal of Leukocyte Biology, 106 (1), 147-160. doi: http://doi.org/10.1002/jlb.3mir1218-483rr 